\title{
Erratum to: Brain Trauma Foundation Guidelines for Intracranial Pressure Monitoring: Compliance and Effect on Outcome
}

\author{
Alberto Aiolfi ${ }^{1}$ Elizabeth Benjamin ${ }^{1} \cdot$ Desmond Khor $^{1} \cdot$ Kenji Inaba $^{1}$ • \\ Lydia Lam $^{1}$ • Demetrios Demetriades ${ }^{1}$
}

Published online: 21 February 2017

(C) Société Internationale de Chirurgie 2017

\section{Erratum to: World J Surg \\ DOI 10.1007/s00268-017-3898-6}

In the original article Lydia Lam's family and given names were interchanged. The original article has been corrected as reflected in this erratum.

The online version of the original article can be found under doi:10.1007/s00268-017-3898-6.

\section{Demetrios Demetriades}

demetria@usc.edu

1 Division of Acute Care Surgery, University of Southern California, 2051 Marengo Street, Inpatient Tower (C), Rm C5L100, Los Angeles, CA 90033, USA 